\title{
Nasopharyngeal linguatulosis or halzoun syndrome: clinical diagnosis and treatment
}

\author{
Umayya Musharrafieh ${ }^{\mathbf{1}, 2}$ \\ Gracia Hamadeh ${ }^{1}$ \\ Anthony Touma \\ (iD) Jawad Fares ${ }^{4}$
}

\begin{abstract}
1. Department of Family Medicine, American University of Beirut Medical Center, Beirut, Lebanon 2. Division of Infectious Diseases, Department of Internal Medicine, American University of Beirut Medical Center, Beirut, Lebanon 3. Faculty of Medicine, American University of Beirut, Beirut, Lebanon 4. Department of Neurological Surgery, Feinberg School of Medicine, Northwestern University, Chicago, IL 60611, USA
\end{abstract}

\section{SUMMARY}

Halzoun syndrome, also known as nasopharyngeal linguatulosis, is a rare entity that is mostly prevalent in Eastern Mediterranean countries. The consumption of raw ovine liver and lymph nodes infested with Linguatula serrata nymphs remains a major cause of the nasopharyngeal symptoms and discomfort associated with the disease. Halzoun syndrome is a clinical diagnosis based on history and presentation. Treatment of this disease is still debated; however, our experience reveals that alcohol gargle can be a good option. Proper counselling on the hazards of eating raw liver in endemic areas is needed. Moreover, physicians should be aware of the sequence of events in the disease in order not to delay or miss the diagnosis. This communication presents a rare Lebanese case of Halzoun syndrome that offers medical implications in the clinical diagnosis and treatment of the nasopharyngeal symptoms of this syndrome, with a review of the literature.

KEYWORDS: Pentastomida. Lebanon. Nasopharyngitis. Parasitic Diseases.

\section{INTRODUCTION}

Halzoun syndrome was originally described in Lebanon, in 1905. It is a rare clinical disease that manifests as an acute allergic-like reaction involving the upper respiratory tract and nasopharyngeal mucosa after the consumption of raw sheep or goat liver, a popular food presentation in Lebanon and other countries of the Eastern Mediterranean region. ${ }^{1}$ At first, this condition was thought to be due to Fasciola hepatica; ${ }^{2}$ alternative suggestions such as Dicrocoelium dendriticum, ${ }^{3}$ Clinostomum complanatum ${ }^{4}$ and, most recently, Linguatula serrata $a^{5}$ have also been made. Consequently, Halzoun is often referred to as nasopharyngeal linguatulosis.
On the basis of clinical presentation, Lebanese Halzoun is congruent with the Marrara syndrome in Sudan. ${ }^{6}$ Marrara is linked to the ingestion of various raw visceral organs of sheep, goats, cattle or camels. In both diseases, discomfort and a pricking sensation deep in the throat occur minutes to hours post prandial (Figure 1). However, expectoration of worms is rarely observed in patients with the Lebanese Halzoun whereas it is quite common in Marrara syndrome. ${ }^{7}$

Few reports exist in the literature exploring Halzoun syndrome (Table 1). ${ }^{1,-21}$ In this paper, we explore the case of a Lebanese patient presenting 
TABLE 1: DOCUMENTED CASES OF HALZOUN SYNDROME AND SIMILAR PRESENTATIONS. NB: ALL CASES REPORTED IMPROVEMENT OF SYMPTOMS WITH TIME.

\begin{tabular}{|c|c|c|c|c|c|}
\hline Author & Year & Case & Source & Treatment & Country \\
\hline Roy and Ganguly ${ }^{8}$ & 1940 & $\begin{array}{l}\text { Female with coughing, sneezing, pain over the region of the } \\
\text { frontal sinuses and discharge of white motile worms }\end{array}$ & Domestic dog & No treatment & India \\
\hline Unat and Sahin ${ }^{9}$ & 1950 & $\begin{array}{l}\text { Female with sneezing, coughing, severe itching in the } \\
\text { throat and nasal discharge of motile organisms }\end{array}$ & $\begin{array}{l}\text { Improperly } \\
\text { cooked ovine } \\
\text { mesenteric lymph } \\
\text { nodes }\end{array}$ & No treatment & Turkey \\
\hline $\begin{array}{l}\text { Watson and } \\
\text { Kerim }^{\mathbf{1 0}}\end{array}$ & 1956 & 23 cases with pharyngeal irritation (Halzoun attack) & $\begin{array}{l}\text { Raw sheep or goat } \\
\text { liver }\end{array}$ & - & Lebanon \\
\hline $\begin{array}{l}\text { Papadakis and } \\
\text { Hourmouziadis }{ }^{\mathbf{1 1}}\end{array}$ & 1958 & $\begin{array}{l}\text { 29-year-old female with acute attack of cough and sneez- } \\
\text { ing, with much rhino-pharyngeal secretion, and allergic } \\
\text { symptoms. Worm-like pieces were expelled several times } \\
\text { with the secretions from the rhino-pharyngeal cavities }\end{array}$ & - & No treatment & Greece \\
\hline $\begin{array}{l}\text { Le Corroller and } \\
\text { Pierre }^{12}\end{array}$ & 1959 & A case with nasopharyngeal linguatulosis & - & - & Morocco \\
\hline Schacher et al. ${ }^{1}$ & 1965 & $\begin{array}{l}26 \text { patients with pain in the throat, severe itching in the } \\
\text { external auditory canals, pain in the ears, tinnitus, paroxys- } \\
\text { mal coughing, hoarseness, dyspnoea, paroxysmal sneezing, } \\
\text { lachrymation, coryza, haemoptysis, epistaxis, submandibu- } \\
\text { lar oedema, and temporary hearing loss }\end{array}$ & Raw goat liver & $\begin{array}{l}\text { No treatment } \\
\text { (One patient } \\
\text { needed oxygen) }\end{array}$ & Lebanon \\
\hline Schacher et al. ${ }^{6}$ & 1969 & $\begin{array}{l}\text { 17-year-old female with itching and tingling in the throat, } \\
\text { dyspnoea, coughing, sneezing and discharging white } \\
\text { worms from the nasals and the mouth } \\
29 \text {-year-old male with a foreign body sensation in the } \\
\text { mouth, coughing, hoarseness, dyspnoea and discharge of a } \\
\text { white organism from the mouth }\end{array}$ & $\begin{array}{l}\text { Raw liver or } \\
\text { lymph nodes of } \\
\text { domestic herbi- } \\
\text { vores }\end{array}$ & No treatment & Lebanon \\
\hline Buslau et al. ${ }^{13}$ & 1990 & $\begin{array}{l}\text { 37-year-old German tourist with coughing, hoarseness, } \\
\text { dysphagia, anosmia, frontal headache, epistaxis and a } \\
\text { papular non-itching exanthema }\end{array}$ & $\begin{array}{l}\text { Improperly } \\
\text { cooked meat }\end{array}$ & No treatment & Tunisia \\
\hline El-Hassan et al. ${ }^{\mathbf{4}}$ & 1991 & $\begin{array}{l}28 \text {-year-old female with itching of the nose, palate and } \\
\text { throat, running from the nose and eyes, and dysphonia }\end{array}$ & Raw goat liver & No treatment & Sudan \\
\hline Yagi et al. ${ }^{\mathbf{1 5}}$ & 1996 & $\begin{array}{l}24 \text { patients who presented with dyspnoea, sneezing, } \\
\text { coughing, dysphagia, dysphonia, facial oedema, headache, } \\
\text { fever, vomiting, itching in the throat and nose, unilateral } \\
\text { conductive deafness, tinnitus and facial palsy }\end{array}$ & $\begin{array}{l}\text { Raw viscera of } \\
\text { goats or sheep }\end{array}$ & $\begin{array}{l}\text { Antihistamines } \\
\text { Antibiotics }\end{array}$ & Sudan \\
\hline Morsy et al. ${ }^{16}$ & 1999 & $\begin{array}{l}\text { 20-year-old male with fever, urticaria (face and neck), } \\
\text { coughing, vomiting and passage of worm-like structures in } \\
\text { his nasal discharge and vomitus }\end{array}$ & - & $\begin{array}{l}\text { Symptomatic } \\
\text { treatment } \\
\text { Praziquantel (1 } \\
\text { dose) }\end{array}$ & Egypt \\
\hline Maleky ${ }^{17}$ & 2001 & 28-year-old female with pharyngeal symptoms & - & Removal & Iran \\
\hline Siavashi et al. ${ }^{18}$ & 2002 & $\begin{array}{l}\text { A } 27 \text {-year-old male and two females aged } 23 \text { and } 43 \text { years } \\
\text { with discomfort and a prickling sensation deep in throat } \\
\text { which extended to the ears, coughing, sneezing, yellow } \\
\text { nasal discharge, dyspnoea, dysphagia and frontal headache }\end{array}$ & $\begin{array}{l}\text { Undercooked } \\
\text { sheep liver }\end{array}$ & $\begin{array}{l}\text { Forceps remov- } \\
\text { al of worms } \\
\text { from larynx, } \\
\text { nose and gums }\end{array}$ & Iran \\
\hline Yilmaz et al. ${ }^{19}$ & 2011 & $\begin{array}{l}\text { 26-year-old female with expectoration of few worms about } \\
4 \mathrm{~cm} \text { long from the oral cavity, sore throat, partial voice } \\
\text { loss, pharyngeal pain, coughing, sneezing and vomiting }\end{array}$ & - & $\begin{array}{l}\text { No treatment } \\
\text { Gargling with } \\
\text { saline solution }\end{array}$ & Turkey \\
\hline Hamid et al..$^{20}$ & 2012 & $\begin{array}{l}\text { A 34-year-old mother and her 12-year-old daughter with } \\
\text { discomfort and pricking sensation in throat with expan- } \\
\text { sion to the ears, coughing, sneezing, yellow nasal and ear } \\
\text { discharges were appeared, epigastric pains, movement of } \\
\text { something in their nose and ears, and discharge of several } \\
\text { organisms through coughing and sneezing }\end{array}$ & Raw goat liver & No treatment & Iran \\
\hline Khalil et al. ${ }^{7}$ & 2013 & $\begin{array}{l}32 \text { patients with moderate to severe pharyngitis, itchiness } \\
\text { of throat and nose, nasal congestion and discharge and } \\
\text { lacrimation }\end{array}$ & $\begin{array}{l}\text { Raw/undercooked } \\
\text { ovine (sheep } \\
\text { or goat) liver } \\
\text { ingestion }\end{array}$ & $\begin{array}{l}\text { Methylpred- } \\
\text { nisolone } \\
(40-80 \mathrm{mg} \\
\text { intramuscular } \\
\text { or intravenous) } \\
\text { injections }\end{array}$ & Lebanon \\
\hline Yazdani et al. ${ }^{21}$ & 2014 & $\begin{array}{l}\text { 32-year-old woman with burning sensation and itching of } \\
\text { the nasopharyngeal region and throat, sneezing, coughing } \\
\text { and respiratory discharges }\end{array}$ & Raw sheep liver & $\begin{array}{l}\text { Cetirizine } \\
\text { and Flixonase } \\
\text { aqueous nasal } \\
\text { spray } \\
\text { Saline solution } \\
\text { (nasal wash) }\end{array}$ & Iran \\
\hline
\end{tabular}


with clinical symptoms of Halzoun syndrome, and discuss the diagnostic and curative aspects of the disease with a review of the literature.

\section{REPORT}

A 20-year-old female, previously healthy, was referred with nasopharyngeal symptoms of two days duration. Described symptoms were discomfort and a bolus sensation deep in the throat. The symptoms were associated with severe rhinorrhoea, coughing, sneezing and mild dyspnoea, and were severe enough to awaken the patient at night. Nausea, vomiting and other gastrointestinal manifestations were not reported. The patient stated that her symptoms started 6-hours after eating raw ovine liver, with five other family members. All family members developed similar symptoms; however, three siblings consumed alcohol during their meal. Their symptoms resolved within 24 hours. The remaining three family members (father, mother and patient) did not consume alcohol during the meal. Before presentation, the patient sought external medical advice and was prescribed oral corticosteroids with no significant improvement. Routine clinical examination and nasopharyngeal check-up showed no significant findings. Based on the clinical symptoms and manifestations, Halzoun syndrome was suspected. She was advised to gargle with alcohol every 4 to 6 hours. Upon follow-up, one week later, the patient reported significant improvement of symptoms. Due to the fact that alcohol gargle is an uncommon and peculiar regimen, the patient sought the advice of another practitioner who prescribed Albendazole for 3 days, despite her improvement.

\section{DISCUSSION}

Halzoun syndrome continues to manifest itself occasionally in the form of an allergic-like pharyngitis. Most of the previously described cases reported a history of raw sheep or goat liver intake (Table 1). Raw liver is a traditional Lebanese dish that is popularly served as part of the Lebanese "Mezza". Often, the symptoms of Halzoun can be mistaken for typical allergies and corticosteroids may be prescribed. The patient did not benefit from oral corticosteroids after two days of adequate steroid administration. Therefore, diagnosis based on clinical presentation and history is crucial.

Nasopharyngeal discomfort, coughing and sneezing are often common during Halzoun attacks. Other symptoms like pain and itching in the external auditory canals, tinnitus, hoarseness, lacrimation, coryza, haemoptysis, epistaxis, headache, submandibular oedema, temporary hearing loss, and papular rash may also be encountered; $; 1$, our patient did not report any of these symptoms.

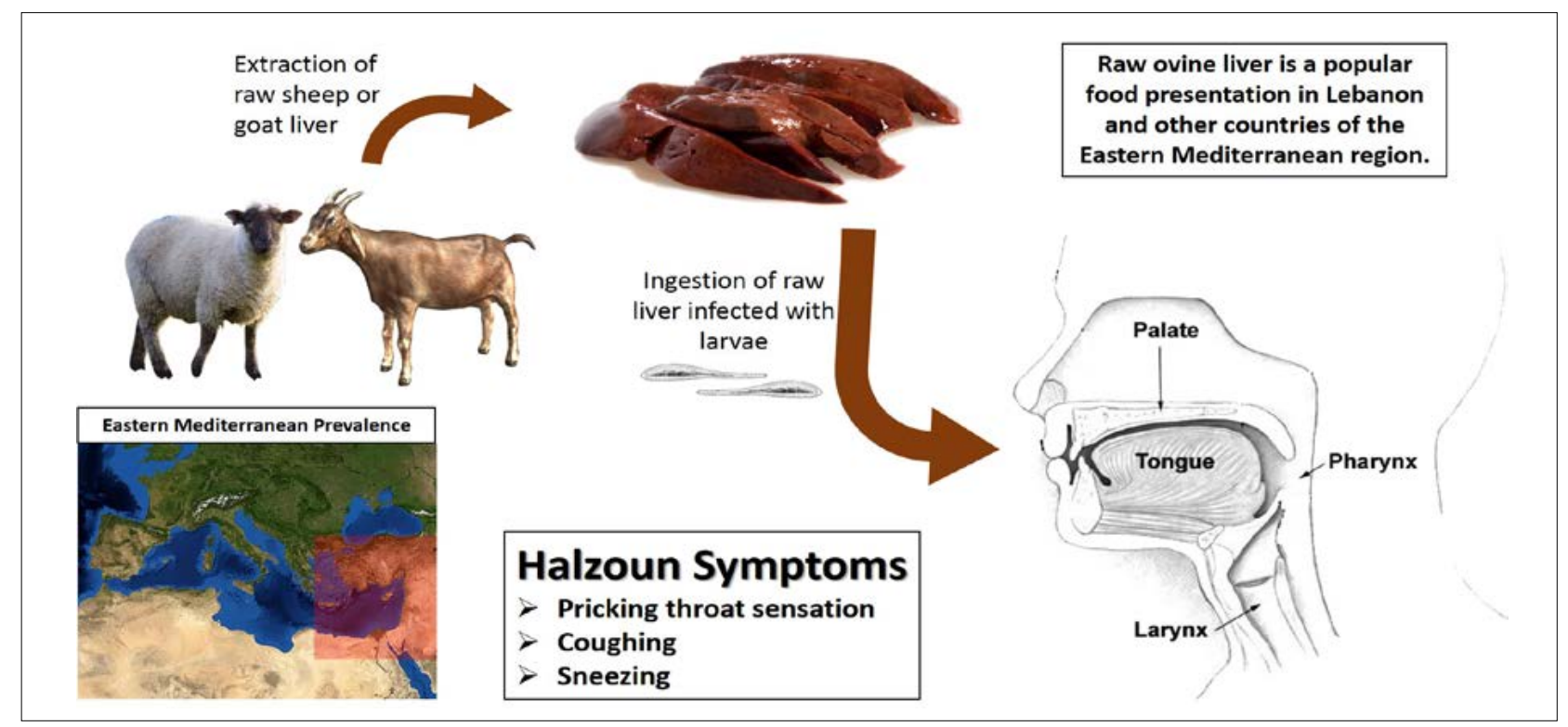

FIGURE 1 Halzoun Syndrome is a result of a buccopharyngeal infection mostly occurring in Lebanon and other Eastern Mediterranean countries. It is thought to be caused by Linguatula serrata worms which attach by their suckers to the soft palate, pharynx and larynx of the human host, after ingestion of infected raw liver or lymph nodes from sheep or goats. Most common symptoms of Halzoun include picking sensation in the throat, coughing and sneezing. 
Resolution of symptoms within 24 hours in family members who ingested alcohol during their meal was a clue to the diagnosis. Other reports suggest that the patient might improve without treatment and that he/she may cough or sneeze the infested worms (Table 1). In Lebanese Halzoun, there are often no worms or only very few non-mobile worms found in the mouth, nasal secretions or throat of patients, making it difficult to expel or retrieve proper samples for pathogen identification. ${ }^{7}$ For this reason, some suggested the administration of emetics that will lead to the expulsion of parasites in the vomitus, ${ }^{2}$ while others suggested the insufflation of lemon powder into the throat to detach parasites from the mucosa. ${ }^{10}$ We believe that alcohol will neutralize the parasites and that the gargle action will help in detaching them.

\section{CONCLUSION}

Alcohol gargle seems to be a good option for the treatment of Halzoun syndrome amid the lack of consensus on other alternative regimens. Proper counselling about the hazards of eating raw liver in endemic areas is needed. Moreover, physicians should be alerted to the chronology of events in the disease in order not to delay or miss the diagnosis.

\section{Ethical Approval}

Patient granted full permission to share and publish all information present.

\section{Conflict of Interests}

None declared.

\section{Funding: None.}

\section{RESUMO}

Esta comunicação apresenta um caso libanês raro de síndrome de Halzoun que oferece implicações médicas no diagnóstico clínico e no tratamento dos sintomas nasofaríngeos desta síndrome, com uma revisão da literatura. A síndrome de Halzoun, também conhecida como linguatulose nasofaríngea, é uma entidade rara predominante nos países do Mediterrâneo Oriental. O consumo de linfonodos ovinos e linfáticos ovinos infestados com ninfas Linguatula serrata continua a ser uma das principais causas dos sintomas nasofaríngeos e do desconforto associado à doença. A síndrome de Halzoun é um diagnóstico clínico baseado na história e na apresentação. O tratamento dessa doença ainda é debatido; no entanto, nossos resultados revelam que o gargarismo de álcool pode ser uma boa opção. É necessário um aconselhamento adequado sobre os perigos de comer fígado cru em áreas endêmicas. Além disso, os médicos devem estar cientes da sequência de eventos na doença, a fim de não atrasar ou perder o diagnóstico.

PALAVRAS-CHAVE: Pentastomídeos. Líbano. Nasopharyngitis. Doenças parasitárias.

\section{REFERENCES}

1. Schacher JF, Khalil GM, Salman S. A field study of halzoun (parasitic pharyngitis) in Lebanon. J Trop Med Hyg. 1965;68(9):226-30.

2. Khouri A. Le halzoun. Arch Parasitol. 1905;9:78-94.

3. Brumpt E. Précis de parasitologie. $5^{\text {th }}$ ed. Paris:Masson et Cie:1936. p.572-3.

4. Witenberg G. What is the cause of the parasitic laryngo-pharyngitis in the near East ("halzoun")?. Acta Med Orient. 1944;3(6):191-2.

5. Khalil GM, Schacher JF. Linguatula serrata in relation to halzoun and the marrara syndrome. Am J Trop Med Hyg. 1965;14(5):736-46.

6. Schacher IF, Saab S, Germanos R, Boustany N. The aetiology of halzoun in Lebanon: recovery of Linguatula serrata nymphs from two patients. Trans R Soc Trop Med Hyg. 1969;63(6):854-8.

7. Khalil G, Haddad C, Otrock ZK, Jaber F, Farra A. Halzoun, an allergic pharyngitis syndrome in Lebanon: the trematode Dicrocoelium dendriticum as an additional cause. Acta Trop. 2013;125(1):115-8.

8. Roy DN, Ganguly SK. Linguatulid infection in man. Ind Med Gaz. 1940;75(8):478.

9. Unat EK, Sahin V. Linguatula serrata sur felerile husule gelen bir infestasiyon hastaligi dolaysile. Istanbul: Universitesi tip Facultesi Mecmuasi; 1950 p.362-9.

10. Watson JM, Kerim RA. Observations on forms of parasitic pharyngitis known as halzoun in the Middle East. | Trop Med Hyg. 1956;59(7):147-54.

11. Papadakis AM, Hourmouziadis AN. Human infestation with Linguatula serrata: report of a case. Trans R Soc Trop Med Hyg. 1958;52(5):454-5.

12. Le Corroller Y, Pierre JL. On a case of human linguatulosis in Morocco. Bull Soc Pathol Exot Filiales. 1959;52:730-3.
13. Buslau M, Kühne U, Marsch WC. Dermatological signs of nasopharyngeal linguatulosis (halzoun, Marrara syndrome): the possible role of major basic protein. Dermatologica. 1990;181(4):327-9.

14. el-Hassan AM, Eltoum IA, el-Asha BM. The Marrara syndrome: isolation of Linguatula serrata nymphs from a patient and the viscera of goats. Trans R Soc Trop Med Hyg. 1991;85(2):309.

15. Yagi H, el Bahari S, Mohamed HA, Ahmed el-R S, Mustafa B, Mahmoud $M$, et al. The Marrara syndrome: a hypersensitivity reaction of the upper respiratory tract and buccopharyngeal mucosa to nymphs of Linguatula serrata. Acta Trop. 1996;62(3):127-34.

16. Morsy TA, El-Sharkawy IM, Lashin AH. Human nasopharyngeal linguatuliasis (Pentasomida) caused by Linguatula serrata. I Egypt Soc Parasitol. 1999;29(3):787-90.

17. Maleky F. A case report of Linguatula serrata in human throat from Tehran, central Iran. Indian | Med Sci. 2001;55(8):439-41.

18. Siavashi MR, Assmar M, Vatankhah A. Nasopharyngeal pentastomiasis (Halzoun): report of 3 cases. Iran J Mol Sci. 2002;27:191-2.

19. Yılmaz H, Cengiz ZT, Çiçek M, Dülger AC. A nasopharyngeal human infestation caused by Linguatula serrata nymphs in Van province: a case report. Turkiye Parazitol Derg. 2011;35(1):47-9.

20. Hamid T, Hossein YD, Mehran BB, Masood FS, Hamid E. A case report of Linguatula serrata infestation from rural area of Isfahan city, Iran. Adv Biomed Res. 2012;1:42.

21. Yazdani R, Sharifi I, Bamorovat M, Mohammadi MA. Human linguatulosis caused by Linguatula serrata in the city of Kerman, South-eastern Iran: case report. Iran J Parasitol. 2014;9(2):282-5. 